Piotr Chomik

Uniwersytet w Białymstoku

\title{
Pomiędzy Polską, Niemcami a Rosją. Przyczynek do dziejów mazurskich filiponów
}

Grzegorz Krassowski, Wspomnienia mazurskiego filipona, opracował, wydał i posłowiem opatrzył Stefan Pastuszewski, Instytut Wydawniczy „Świadectwo”, Bydgoszcz 2014, ss. 64.

Pierwsi staroobrzędowcy osiedlili się na ziemiach dawnej Rzeczypospolitej już pod koniec XVII w. Wzmianki o nich zaczęły pojawiać się w piśmiennictwie rosyjskim i niemieckim u schyłku XVIII w. Do połowy XIX stulecia jednak coraz liczniejsze wzmianki o staroobrzędowcach w Polsce nie miały charakteru naukowego. Opisywano w nich zwyczaje staroobrzędowców, stroje, przyczyny przesiedlania się na obszar Rzeczypospolitej czy wewnętrzne konflikty w łonie samych staroobrzędowców. Wyjątek stanowiły informacje oparte na danych urzędowych czy archiwalnych zawarte w pracach M. Giersza, F. Tetznera czy E. Titiusa ${ }^{1}$.

Z XIX-wiecznych prac polskich warto zwrócić uwagę na opracowanie B. Tykla, Kilka uwag historyczno-statystycznych o guberni augustowskiej. O tak zwanych Filiponach $w$ guberni augustowskiej zamieszkatych, wydrukowane w periodyku „Biblioteka Warszawska” w 1857 r., oraz na anonimowe opracowanie zatytułowane Wiadomości o Filiponach, opublikowane w roczniku cesarsko-królewskiego Towarzystwa Naukowego Krakowskiego w 1861 r. $^{2}$ Należy wspomnieć też o pracy ks. Karola Dębińskiego, Raskoł i sekty Prawosławnej Cerkwi Rosyjskiej (Warszawa

${ }^{1}$ E. Iwaniec, Z dziejów staroobrzędowców na ziemiach polskich XVII-XX w., Warszawa 1977, s. 12-13 (rec. w: „Acta Baltico-Slavica” 13 [1980], s. 264; I. Grek-Pabisowa, Kierunki i stan badań nad staroobrzędowcami w Polsce, w: Studia językowe z Białostocczyzny. Onomastyka i historia języka, cz. 1, red. I. Maryniakowa, E. Smułkowa, Białystok 1989 (Prace Białostockiego Towarzystwa Naukowego, t. 33), s. 141-150.

2 I. Grek-Pabisowa, op. cit., s. 141. Jak zauważyła I. Grek-Pabisowa, według L. Finkla autorem opracowania był Karol Mecherzyński; Bibliografia historii polskiej, t. 1, Warszawa 1955, s. 781. 
1910). Była to pierwsza w języku polskim praca zawierająca ogólny zarys historii powstania staroobrzędowców (traktowanych przez autora jako sekta), naukę poszczególnych odłamów oraz wiele danych dotyczących życia staroobrzędowców. Autor opracowania twierdził, że przyczyną przybycia staroobrzędowców na tereny Rzeczypospolitej, a także na obszar Prus i Wołoszczyzny, były prześladowania ze strony władz ${ }^{3}$.

Z książki Eugeniusza Iwańca czerpiemy wiedzę o wydanych w okresie międzywojennym publikacjach dotyczących starowierów, a było ich całkiem niemało. Niemniej zawierały informacje - jak pisała Iryda Grek-Pabisowa - skąpe, jednorodne i często wypaczone $e^{4}$.

Pomimo tego zastrzeżenia warto wymienić prace Wiktora Piotrowicza, $Z$ zagadnień wyznaniowych $w$ Polsce, Wilno 1929; Wyznania religijne $w$ województwie wileńskim, w: Wilno i ziemia wileńska, Wilno 1930; Staroobrzędowcy w Polsce, „Słowo” 6 (1927); Uregulowanie położenia prawnego Kościoła staroobrzędowego, „Kurjer Wileński” 5 (1928), nr 218. Eugeniusz Iwaniec wymienia także - wydaną w Warszawie w 1933 r. - pracę Jędrzeja Giertycha, Za pótnocnym kordonem (Prusy Wschodnie), w której znalazł się rozdział Śród Filiponów nad Krutynia, oraz pracę ks. Stefana Grelewskiego, Wyznania protestanckie i sekty religijne w Polsce współczesnej, Lublin 1937. Zauważa także wydany w 1937 r. reportaż Melchiora Wańkowicza Na tropach Smętka i znajdujący się w nim rozdział „O Filiponach”, w którym autor opisuje życie staroobrzędowców ze wsi Wojnowo. Do tego reportażu Iwaniec odniósł się bardzo krytycznie, stwierdzając, że jego treść jest powszechnie kwestionowana przez ogół staroobrzędowców5.

W różnych miejscach swojej książki Eugeniusz Iwaniec wspomina też artykuły Stanisława Srokowskiego, Ludność Prus Wschodnich (Warszawa 1937) i Erwina Koschmiedera, Teoria i praktyka rosyjskiego śpiewu neumatycznego na tle tradycji staroobrzędowców wileńskich („Ateneum Wileńskie” 10 [1935]).

Wspomniani Piotrowicz i Srokowski w swych opracowaniach przychylnie ustosunkowywali się do staroobrzędowców. Piotrowicz nazywał ich „najlojalniejszymi obywatelami przybranej ojczyzny”, podkreślając przy tym różnice w traktowaniu staroobrzędowców przez rząd Rosji carskiej i rząd Polski. Srokowski natomiast, omawiając mniejszości narodowe w Polsce, zaznaczał, że staroobrzędowcy „nigdy nie korzystali z opieki społeczeństwa rosyjskiego, rząd zaś niemiecki czynił wszystko co mógł, by ich zgermanizować”. Zauważał przy tym, że staroobrzędowcy nie dali się zgermanizować, w przeciwieństwie do łatwo germanizujących się Litwinów ${ }^{6}$.

Cennymi opracowaniami z okresu międzywojennego, niezauważonymi przez Iwańca, są wymienione przez Irydę Grek-Pabisową dwie prace Zofii Licharewej,

\footnotetext{
${ }^{3}$ I. Grek-Pabisowa, op. cit., s. 141-142.

4 Ibidem, s. 142.

${ }^{5}$ E. Iwaniec, op. cit., s. 15.

${ }^{6}$ I. Grek-Pabisowa, op. cit., s. 142-143.
} 
opublikowane w popularnonaukowym czasopiśmie „Oriens” w 1938 i 1939 r. Pierwszy tekst: $U$ źródeł starowierstwa rosyjskiego, zamieszczony został ku uczczeniu „małego jubileuszu prawnego uregulowania egzystencji tego odłamu wschodniego chrześcijaństwa". Autorka zauważa, że starowierzy w Polsce stanowią niemałą grupę, bo liczącą około 50 tys., i stara się cofnąć w swym tekście do źródeł starowierstwa w ogóle, by umożliwić czytelnikowi lepsze zrozumienie tego wyznania. W kolejnym tekście, zatytułowanym Dzieje starowierstwa rosyjskiego, autorka omawia historię staroobrzędowców w Rosji do rewolucji październikowej i wyraźnie daje do zrozumienia zamiar kontynuowania tematu, w tym dziejów osadnictwa staroobrzędowców w Rzeczypospolitej. Niestety, wybuch II wojny światowej uniemożliwił dalsze publikacje?.

Nowy okres w badaniach nad dziejami staroobrzędowców w Polsce nastąpił po II wojnie światowej. Badacze rozpoczęli pracę od zgromadzenia podstawowych informacji o staroobrzędowcach. Wcześniejsza literatura problemu zawierała opis dziejów rozłamu w Kościele prawosławnym, przedstawienie nauki i teologii staroobrzędowców oraz prezentację podziałów w łonie staroobrzędowców i stosunek do nich władzy carów i moskiewskiego Kościoła prawosławnego. Badacze wiedzieli również, jakie regiony Polski zamieszkują staroobrzędowcy, jakie mają obyczaje i zwyczaje dnia codziennego. Wiele z tych informacji jednak było przestarzałych lub po prostu nieprawdziwych. Dlatego też - jak opisuje to Grek-Pabisowa - pierwsze powojenne publikacje o staroobrzędowcach miały charakter informujący. Były to: artykuł samej Grek-Pabisowej, Niektóre wiadomości o starowierach zamieszkałych na terenie Polski, „Slavia Orientalis” 8 (1958), nr 4; tekst Lili Szwengrub, Z badań terenowych. Filiponi, „Euhemer. Przegląd Religioznawczy” 2 (1958), nr 2-3; opracowanie Wiktora Jakubowskiego, $Z$ historii kolonii staroobrzędowców rosyjskich na Mazurach, „Slavia Orientalis” 10 (1961), nr 1. W latach 1964-1965 pojawily się też pierwsze teksty Eugeniusza Iwańca, zamieszczane w rosyjskojęzycznym czasopiśmie „Russkij Gołos”. Wszystkie te prace dotyczyły dziejów, kultury, religioznawstwa, językoznawstwa oraz etnografii i wiedzy o książce staroobrzędowej ${ }^{8}$.

Ważną pracą był obszerny artykuł Emilii Sukertowej-Biedrawiny, Filiponi na ziemi mazurskiej, „Komunikaty Mazursko-Warmińskie” 71 (1961), nr 1. Autorka omówiła takie problemy, jak: filiponi w piśmiennictwie niemieckim, emigracja filiponów z Polski (jej przyczyny), pionierzy filipońscy, stabilizacja staroobrzędowców na Mazurach, zwyczaje i wierzenia filiponów, zasady religijne, księgi liturgiczne i religijne oraz życie współczesne filiponów w Polsce9 .

Bardzo ważne prace dotyczące staroobrzędowców na ziemiach polskich wyszły spod pióra Eugeniusza Iwańca. Przez wiele lat prowadził on badania historyczne zarówno w terenie, jak i w archiwach polskich i łotewskich (wówczas w ZSRR).

\footnotetext{
7 Ibidem, s. 143.

8 Ibidem, s. 143-144.

9 Ibidem, s. 145.
} 
Zawarł też znajomości ze staroobrzędowcami na Łotwie i w Rosji, i od nich otrzymał wiele cennych informacji na temat staroobrzędowców. Zajmując się staroobrzędową drukarnią słowiańską w Piszu, po żmudnych poszukiwaniach zgromadził wszystkie roczniki drukowanego tam w latach 1863-1868 czasopisma „Istina” oraz inne wydawane w Piszu druki. Jak sam pisał: „W ten sposób stałem się jedynym w Polsce posiadaczem większości druków wydanych przez tę oficynę, rzadko notowanych w katalogach bibliotek polskich, rosyjskich i innych"10.

Z opublikowanych przez Iwańca innych prac wymienić należy jeszcze obszerne artykuły o staroobrzędowcach w Augustowskiem, Sejneńskiem, i Suwalskiem: Osadnictwo staroobrzędowców w powiecie augustowskim (w: Studia i Materiały do dziejów Pojezierza Augustowskiego, Białystok 1967, s. 401-428), Staroobrzędowcy (w: Mragowo. Z dziejów miasta i powiatu, Olsztyn 1975, s. 217-235), Staroobrzędowcy $i$ ich tradycje kulturalne w Sejneńskiem (w: Materiały do dziejów ziemi sejneńskiej, t. 2, Warszawa 1975, s. 393-429) ${ }^{11}$.

Materiały $\mathrm{z}$ tych artykułów zostały wykorzystane przez Iwańca $\mathrm{w}$ już wspominanej tu pracy: $Z$ życia staroobrzędowców na ziemiach polskich XVII-XX w. Owa składająca się z siedmiu rozdziałów publikacja łączy elementy historyczne, religioznawcze i etnograficzne. Autor omawia w niej formowanie się głównych wspólnot staroobrzędowych i ich zasady wiary, osiedlanie się staroobrzędowców na ziemiach dawnej Rzeczypospolitej, dzieje staroobrzędowców na obszarze dawnych województw: białostockiego i olsztyńskiego (na Mazurach). Opisuje także elementy tradycyjnej kultury staroobrzędowców, zarówno religijnej (budownictwo sakralne, ikony, księgi, krzyże, wyposażenie świątyń, odzież mniszek), jak i materialnej (budownictwo mieszkaniowe, łaźnie, odzież dzieci i osób dorosłych, żywność i używki). Jak zauważyła Iryda Grek-Pabisowa, autor wykazał się dokładną znajomością przedmiotu oraz wiedzą o problemach staroobrzędowców w Polsce i za granicą, pewnym niedostatkiem był natomiast brak niezbędnego w części historycznej tła politycznej i społeczno-ekonomicznej sytuacji Rzeczypospolitej na przełomie XVII i XVIII w. Prezentacja tej sytuacji doskonale wyjaśniałaby bowiem, dlaczego prześladowana za swe wierzenia ludność uciekała z terytorium Rosji na obszar Rzeczypospolitej. Pamiętać przy tym należy, że właśnie na przełomie XVII i XVIII w. malało znaczenie Polski na arenie międzynarodowej, a pod względem

10 E. Iwaniec, „Stawianskaja Tipografija” w Piszu w dziejach staroobrzędowców, jedinowierców i prawosławnych, w: Prawosławne oficyny wydawnicze w Rzeczypospolitej, red. A. Mironowicz, U. Pawluczuk, P. Chomik, Białystok 2003, s. 165. Na temat drukarni słowiańskiej badacz ten opublikował także artykuły: Kontakty środowiska „Kołokoła” ze staroobrzędowcami na Mazurach, „Zeszyty Naukowe Uniwersytetu Łódzkiego", seria I (1975), nr 111, s. 199-203; Wydawnictwa Drukarni Słowiańskiej na Mazurach w latach sześćdziesiątych XIX stulecia, „Slavia Orientalis” 225 (1976), nr 2, s. 229-337. Dziejom Drukarni Słowiańskiej w Piszu była poświęcona również rozprawa habilitacyjna E. Iwańca, Droga Konstantyna Gołubowa od starowierstwa do prawosławia. Karty $z$ dziejów duchowości rosyjskiej w drugiej połowie XIX wieku, Białystok 2001.

11 I. Grek-Pabisowa, op. cit., s. 146. 
wyznaniowym rosło znaczenie Kościoła rzymskokatolickiego, przy jednoczesnym słabnięciu wszystkich Kościołów mniejszościowych ${ }^{12}$.

$\mathrm{Z}$ innych prac Eugeniusza Iwańca wymienić należy artykuły: Folklor staroobrzędowców na ziemiach polskich („Studia Polono-Slavica Orientalia” 7 [1981]), Wierzenia i obrzędy grzebalne wczoraj i dziś na ziemiach polskich (w: Chrześcijański wschód a kultura polska, red. r. Łużny, Lublin 1989), Folklor staroobrzędowców na ziemiach polskich („Studia Polono-Slavia Orientalia. Acta Literaria” 8 [1984]) ${ }^{13}$. Interesujący jest także artykuł, który powstał podczas pracy nad rozprawą habilitacyjną i dotyczył częściowo dziejów Drukarni Słowiańskiej w Piszu: Paweł Pruski (1821-1895) i jego działalność na Mazurach („Zeszyt Muzeum Warmii i Mazur” 4 [2000], nr 4, s. 33-55).

Spośród dorobku badaczy publikujących od lat 50, po 70. XX w. warto wymienić prace filologów rusycystów. Mam tu na myśli wspomnianego już Wiktora Jakubowskiego i Antoniego Mironowicza, który zapoczątkował badania nad gwarą staroobrzędowców w Polsce. Jego uczennicą była Iryda Grek-Pabisowa, autorka kilkudziesięciu prac dotyczących staroobrzędowców w Polsce. Ich wybór został opublikowany w tomie: Staroobrzędowcy. Szkice z historii, języka, obyczajów, Warszawa 1999. Tom zawierał wybór prac Grek-Pabisowej z lat 1958-1997 ${ }^{14}$. Kontynuatorką tej linii badań była Irena Maryniakowa, zajmująca się składnią gwary staroobrzędowców. Poświęciła ona tej tematyce dwie monografie i wiele artykułów. W swoich pracach wykazała „zadziwiającą konserwatywność [staroobrzędowców] w zachowaniu rodzimego systemu językowego"15.

Autorką kilku ważnych publikacji o staroobrzędowcach jest Zoja Jaroszewicz-Pieresławcew. Przedmiotem jej zainteresowania badawczego były księgi cerkiewne starowierów, którym poświęciła artykuły: Księgozbiór klasztoru staroobrzędowców $w$ Wojnowie (w: Z badań nad polskimi ksiegozbiorami historycznymi, t. 9, red.

12 Ibidem. Zob.: P. Laval, Eugeniusz Iwaniec, „Z dziejów staroobrzędowców na ziemiach polskich”, Warszawa 1977...., recenzja w: „Acta Baltico-Slavica” 13 (1980), s. 264.

13 S. Pastuszewski, Literatura naukowa o staroprawosławiu (5), http://akant.org/45-dodatki/inflanty/4212-stefan-pastuszewski-literatura-naukowa-o-staroprawosawiu-5 (dostęp: 8.02.2016).

14 Ibidem. Spośród wielu prac I. Grek-Pabisowej wymieniam tylko niektóre: Rosyjska gwara starowierców w województwach olsztyńskim i białostockim, Wrocław 1968; Słownictwo rosyjskiej gwary staroobrzędowców mieszkających w Polsce. Rozwój i stan dzisiejszy, Wrocław 1983; Kształtowanie się leksyki rosyjskiej wyspy gwarowej na tle dziejów grupy społecznej, „Acta Baltico-Slavica” 13 (1980), s. 189-212; Zapożyczenia w rosyjskiej gwarze staroobrzędowców w Polsce, cz. 1: Typy zapożyczeń i sposoby przyswajania wyrazów polskich, „Studia z Filologii Polskiej i Słowiańskiej” 22 (1983), s. 47-64, cz. 2: Typy zapożyczeń i sposoby przyswajania wyrazów niemieckich, „Studia z Filologii Polskiej i Słowiańskiej” 23 (1985), s. 163-174; Kompletny spis publikacji I. Grek-Pabisowej można znaleźć pod adresem: http://ispan.waw.pl/default/images/bibliografie_pracownikow/Pabisowa/Pabis\%20I\%20\%20publikacje\%202013.pdf (dostęp: 8.02.2016).

${ }^{15}$ I. Maryniakowa, Imiesłowy $w$ rosyjskiej gwarze starowierców mieszkajacych $w$ Polsce, Wrocław 1976; eadem, Funkcje składniowe bezokolicznika w gwarze pskowskiej $i$ w gwarze Rosjan-starowierców mieszkających w Polsce (Studium porównawcze), Wrocław 1982. Por. I. Grek-Pabisowa, op. cit., s. 148-149. 
B. Bieńkowska, Warszawa 1986, s. 158-180), Księgi liturgiczne staroobrzędowców z klasztoru w Wojnowie w zbiorach Biblioteki Muzeum Warmii i Mazur („Rocznik Olsztyński” 16 [1989], s. 229-254).

Jaroszewicz-Pieresławcew opublikowała też książkę: Starowiercy w Polsce i ich księgi (Olsztyn 1995). W tej zawierającej trzy rozdziały pracy autorka omówiła dzieje starowierów na ziemiach polskich, drukarstwo starowierskie oraz księgozbiory prywatne, klasztorów i molenn. Wśród aneksów znalazły się spisy wspomnianych księgozbiorów, a także spis druków starowierskich wydanych w Rzeczypospolitej w XVIII w. i w Prusach Wschodnich w latach 1860-1867.

Spośród najnowszych opracowań Zoji Jaroszewicz-Pieresławcew o starowierach wymienić można: Starowiercy-bezpopowcy u progu XXI wieku (w: Veritas Christi Liberat. Ksiega Pamiątkowa ku czci Księdza Biskupa Jacka Jezierskiego w 65. rocznice urodzin, 40. rocznice kapłaństwa i 20. rocznice biskupstwa, red. K. Parzych-Blakiewicz, ks. P. Rabczyński, ks. J. Maciej Wojtkowski, Olsztyn 2014, s. 303-313), Miejsce starowierców w życiu społeczności wiejskiej w Rzeczypospolitej od końca XVII do początku XXI wieku (w: Rosjanie - historia i kultura. Sesja naukowa Szreniawa, 27 czerwca 2014, red. A. Kijas, Szreniawa 2014, s. 45-64), Kultura religijna i duchowa starowierców okręgu suwalsko-sejneńskiego $w$ drugiej połowie XX wieku (w: W krainie wielu tradycji. Badania etnograficzne na pograniczu polsko-litewsko-białoruskim w XX i poczatkach XXI wieku, red. K. Snarski, A. Żulpa, Warszawa-Suwałki 2014, s. 155-166), Tekstowe i plastyczne wizje czasu Apokalipsy w piśmiennictwie starowierców (w: Czas Apokalipsy. Wizje dni ostatecznych w kulturze europejskiej od starożytności do wieku XVII, red. K. ZalewskaLorkiewicz, Warszawa 2013, s. 120-126, + il. 3-15), Edukacja religijna dzieci starowierców w Polsce (w: Historia i pamięć. Studia $z$ dziejów XX wieku, red. nauk. W. Gieszczyński, W.B. Łach, K. Sacewicz, Olsztyn 2011, s. 459-469).

W kontekście badań nad książką starowierską wspomnieć należy o Joannie Orzechowskiej, która w 2012 r. wydała monografię poświęconą wojnowskiemu sinodikowi. Sinodik ten został odnaleziony w 2006 r. i zawierał informacje o zmarłych, których należy wspominać podczas nabożeństw, ze szczególnym uwzględnieniem zasłużonych dla klasztoru staroobrzędowców w Wojnowie. Badaczka ta jest również autorką kilkunastu artykułów naukowych poświęconych dziejom, kulturze i językowi staroobrzędowców w Polsce ${ }^{16}$.

${ }^{16}$ J. Orzechowska, Войновский синодик. Лингвокултурологическое описание, Olsztyn 2012; eadem, Rosyjscy staroobrzędowcy w Polsce. Stan badań i perspektywy badawcze, w: Poccur и Польша: Полоника в этнокультурном пространстве. Сборник материалов Международной заочной научно-практической конференции, Уфа 2007, s. 93-95; еаdет, Старообрядческий Войновский Синодик, w: Семантика. Функиионирование. Текст. Межвузовский сборник научных трудов с международным участием, Киров 2008, s. 203-210; еadem, Старообрядческий Войновский Синодик. Время и место издания, „Slavia Orientalis” 57 (2008), nr 2, s. 203-210; еаdem, К вопросу о месте и времени издания богослужебных книг старообрядческого монастыря в Войново. Система сигнутур и фолияиии, „Przegląd Rusycystyczny” 125 
Od lat badania nad gwarą i tradycjami staroobrzędowców prowadzi Instytut Filologii Słowiańskiej Uniwersytetu Mikołaja Kopernika w Toruniu. Badania Stefana Grzybowskiego $^{17}$, Michała Głuszkowskiego ${ }^{18}$ oraz Doroty Paśko-Koneczniak ${ }^{19}$ zaowocowały wieloma nowymi obserwacjami i wnioskami.

(2009), nr 1, s. 5-12; еаdет, Структура Войновского Синодика, w: Семантика..., s. 217-226; еаdет, Орнаментика книг Войновского монастыря. К вопросу о времени и месте издания, „Acta Neophilologica” 11 (2009), s. 5-17; еadem, Герменевтическое изучение текста Войновского синодика, ш: Русский язык и проблемы современного образования. Сборник научных статей, вып. 2: Архангельск 2009, s. 114-124; еadem, Актуализация концепта 'память' в старообрядческом Войновском синодике, „Przegląd Rusycystyczny” 130 (2010), n 2, s. 74-88; еадет, Экстралингвистические компоненты поминального дискурса (на материале старообрядческого Войновского синодика), „Acta Neophilologica” 12 (2010), s. 17-25; eadem, Charakterystyka Wojnowskiego Staroobrzędowego Sinodiku, w: Staroobrzędowcy za granica, Toruń 2010, s. 206-221; eadem, Z historii księgozbioru staroobrzędowego klasztoru w Wojnowie, w: Słowianie wschodni na emigracji. Literatura, kultura, język, red. B. Kodzis, M. Giej, Opole 2010 (Studia i szkice slawistyczne, t. 10), s. 457-464; еаdет, Контент-анализ Войновского синодика, „Acta Neophilologica” 13 (2011), s. 113-134; еadem, ПОМИНОВЕНИЕ как концепт (на материале старообрядческого Войновского синодика, „Acta Polono-Ruthenica” 15 (2010), s. 233-240; eadem, Analiza zawartości Synodyku Wojnowskiego, „Zeszyty Naukowe” 2011, Wyższa Szkoła Języków Obcych w Świeciu, s. 35-46; eadem, Идеи слов синодик и помянник (на основе тексико-семантической характеристики Войновского синодика), w: Дар слова. Сборник статей к юбилею Аллы Алексеевны Камаловой, Северодвинск 2011, s. 90-104; еаdет, Реализация магической функиии в Войновском синодике, „Acta Polono-Ruthenica” 16 (2011), s. 393-401; eadem, Metodologia opisu systemowego zabytku kultu religijnego, w: Язык и текст в системном и социо-культурном аспекте, Olsztyn 2011, s. 45-78; еаdет, Функиия конфессиональной дифференциации религиозного дискурса старообрядиев (на материале Войновского синодика), „Acta Neophilologica” 14 (2012), nr 1, s. 129-137; еadem, Традиции обучения церковнославянскому языку в азбуках из коллекиии Войновского монастыря, Actа Neophilologica" 15 (2013), nr 1, s. 117-124; еаdет, Скитские покаяния из коллекции Войновского монастыря (происхождение и структура), w: Staroobrzędowcy za granica 2, Historia, religia, język, kultura, red. D. Paśko-Koneczniak, M. Ziółkowska, S. Grzybowski, M. Głuszkowski, Toruń 2014; s. 329-335; еаdет, Азбуки в книжных собраниях мазурских старообрядцев, w: Православие в славянском мире: история, культура, язык, red. H. Pociechna, A. Kravetsky, Olsztyn 2014, s. 162-175; еаdет, Функииональная специфика старообрядческого Войновского синодика, w: Fontes Slavia Orthodoxa. Православная культура вчера и сегодня, red. H. Pociechna, A. Kravetsky, Olsztyn 2015, s. 303-319; eadem, Milionerzy i filantropii. O sponsorach klasztoru $w$ Wojnowie $z$ dedykacji ksiaż̇kowych, w: Rosja $w$ dialogu kultur, red. B. Żejmo, s. 65-74; eadem, Grzeszyć słowem. O fragmencie językowego obrazu świata wartości staroobrzędowców na podstawie „Spowiedzi pustelniczej”, „Prace Językoznawcze” 17 (2015), nr 2, s. 67-73.

17 Wymieniam niektóre publikacje S. Grzybowskiego dotyczące staroobrzędowców: Русский островной говор в польском языковом окружении, w: Русско-польские языковые, литературные и культурные контакты, ред. С. Гжибовский, В. А. Хорев, М. Волос, Москва 2011, s. 45-59 (współautor: M. Głuszkowski); Социолингвистическая ситуация старообрядиев в деревнях Габове Гронды и бур (Польша), w: Русские старообрядиы: язык, культура, история. Сборник статей к XIV Международному съезду славистов, ред. Л.Л. Касаткин, Языки славянских культур, Москва, 2008, s. 200-214; Особенности безударного вокализма русского говорв старообрядиев дю Габове Гронды и Бур в Польше, w: Актуальные проблемы русской диалектологии и исследования старообрядчества. Тезисы докладов международной конферениии 
Nie sposób w tym omówieniu polskiej literatury naukowej pominąć prace Stefana Pastuszewskiego. Jest on znany przede wszystkim jako autor zbiorów opowiadań i wierszy, ale prowadzi też działalność naukową i popularnonaukową. Uzyskał stopień doktora na podstawie rozprawy Polska i Polacy a staroprawosławie w XIX i XX wieku, obronionej na Uniwersytecie Kazimierza Wielkiego w Bydgoszczy. W miesięczniku literackim „Akant”, którego jest sekretarzem, publikuje nie tylko własne teksty, ale również opracowania innych autorów traktujące o starowierach ${ }^{18}$.

Nie jest moim celem opisywanie, w ramach tego ograniczonego objętościowo artykułu, okoliczności rozłamu w Kościele prawosławnym, który doprowadził do powstania starowierów jako grupy wyznaniowej z odrębną od prawosławia kulturą religijną. Nie zamierzam również opisywać dokładnie dziejów ich wędrówki w granice Wielkiego Księstwa Litewskiego i Korony. Faktem jest, że przesiedlanie się starowierów na ziemie WKL rozpoczęło się już w wieku XVII, a uaktywniło się po rozbiorach Polski, pod koniec XVIII w. Mieszkali oni w ośmiu z jedenastu powiatów guberni wileńskiej: jezioroskim, kowieńskim, wiłkomirskim, święciańskim, poniewieskim, wileńskim, trockim i oszmiańskim ${ }^{19}$.

19-21 октября 2009 г., Москва 2009, s. 52-53; К вопросу о типе «яканья» в старообрядческом говоре д. Габове Гронды и Бур в Польше, w: Staroobrzędowcy za granica. Historia. Religia. Język. Kultura. Międzynarodowa Konferencja. Tezy wystąpień, Toruń, 26-27.06.2008, s. 23-24.

18 Wymieniam niektóre prace S. Pastuszewskiego: Starowierzy w Polskiej literaturze pięknej, „Podlaski Kwartalnik Kulturalny" 4 (2013), s. 7-29; Starowiercy polskiej Łatgalii a Powstanie Styczniowe, w: Staroobrzędowcy za granica II..., s. 255-269; Przemiany tożsamości staroobrzędowców w Polsce po II wojnie światowej, w: Idea wielokulturowości jako wyzwanie, red. H. Czakowska, ks. M. Kuciński, Bydgoszcz 2015, s. 125-150. Zainteresowanych publikacjami w miesięczniku „Akant” odsyłam na stronę internetową: www.akant.org. Tutaj wymieniam jedynie wybrane tytuły prac S. Pastuszewskiego: Literatura naukowa o staroprawosławiu, Inflancko-polski klin staroobrzędowy, Staroprawosławie w Afryce, Odkrycia i aktualia ze sfery staroprawosławia, Staroprawosławie a Polska i Polacy, Po co badać staroprawosławie.

19 Z. Jaroszewicz-Pieresławcew, Starowiercy w Polsce i ich księgi, Olsztyn 1995, s. 18. Problematyką starowierów na ziemiach Wielkiego Księstwa Litewskiego zajmował się litewski badacz Grigorijus Potasenko. Wymieniam kilka jego najważniejszych prac z tego zakresu: Г. Поташенко, В. Барановский, Староверие Балтии и Польши: краткий исторический и биографический словарь, Vilnius 2005; Г. Поташенко, Староверие в Литве: вторая половина XVII-начало ХІХ вв. Исследования, документы и материаль, Vilnius 2006; idem, Historic and Cultural Heritage Sites of the Old Believers in Lithuania, Washington 2006; idem, История Каунасской старообрядческой общины, Vilnius 2008; idem, «Хронограб Литовский, сиречь Летописеи, степенный Древлеправославнаго Христианства» как исторический источник и памятник старообрядческой историографической мысли ХІХ века, w: Хронограф Литовский, сиречь Летописеи, степенный Древлеправославнаго Христианства, подготовлено Н. Морозовой и Г. Поташенко, Вильнюс 2011, s. 47-87; idem, Роль и значение Рижской Гребенщиковской старообрядческой общины в истории староверия, w: Latvijas vecticībnieki: identitātes saglabāšanas vēsturiskā pieredze. Rak stu krājums, sastādītāji I. Ivanovs, N. Pazuhina, I. Runce = Латвийские староверы: исторический опьт сохранения идентичности. Сборник статей, сост.: И. Иванов, Н. Пазухина, И. Рунце, Rīga 2014, s. 21-53. 
Na ziemię suwalską i sejneńską starowierzy przybyli z Kurlandii, Ukrainy i ziemi nowogrodzko-pskowskiej. W 1779 r. uzyskali od władz polskich dokument zapewniający im swobodne odbywanie praktyk religijnych. W 1780 r. starowierzy osiedlili się w na prawach czynszu we wsiach miejscowościach Gausty i Czuwaniszki ${ }^{20}$. Następnie zaczęto ich osiedlać w nowych wsiach dóbr królewskich. W powiecie sejneńskim starowierzy założyli wsie Głuszyn-Moskale i Budzisko Moskale (obecnie Buda Ruska). Większość osiedli staroobrzędowców powstało w północnej części Puszczy Przełomskiej, między dobrami kamedulskimi a dawną Puszczą Merecką. Pewną rolę w osadnictwie starowierów odegrali też dominikanie, ściągając ich po 1795 r. do wsi Marynowo ${ }^{21}$.

Osiedlający się w Puszczy Przełomskiej starowierzy byli zwolnieni z płacenia podatków na sześć lat, dopiero po tym okresie musieli płacić czynsz z każdej włóki litewskiej i podymne. Posiadali też swobodę odbywania praktyk religijnych. Pierwsze nabożeństwa odbywały się we wsi Głęboki Rów, koło Jeleniewa. Drugi budynek postawiono we wsi Huta, koło Filipowa ${ }^{22}$.

Mało wiadomo o pierwszych starowierach, którzy osiedlili się w powiecie augustowskim. Pojawili się oni tam w XVIII w., m.in. we wsi Pijawne Moskiewskie (później: Pijawne Ruskie). Istnieją przekazy ustne wśród mieszkańców Gabowych Grądów i Augustowa, mówiące o przybyciu starowierów na te ziemie ze wsi Pilczyn koło Góry Kalwarii. Inna tradycja głosi, że starowierzy przywędrowali tu z północnych terenów Rosji, znad Morza Białego, i dlatego są im bliskie tradycje wspólnoty Pomorców z głównym ośrodkiem nad rzeką Wyg ${ }^{23}$.

Otton Hedemann podawał, powołując się na Henryka Merczynga, że za czasów króla Stanisława Augusta Poniatowskiego starowierzy stanowili 1\% społeczeństwa Rzeczypospolitej. Oznacza to, że ich liczbę można określać na 90 tysięcy. Eugeniusz Iwaniec za Tadeuszem Korzonem szacował liczbę starowierów w tym okresie na 100 tys. osób. Statystyczne ujęcie liczby starowierów było bardzo trudne, nie tylko dlatego, że często się przemieszczali, starając się unikać nadzoru władz. Uważali bowiem wszelką statystykę, sprawy urzędowe, pieczęcie, itp. za znaki antychrystusowe. Pierwsze udane próby uporządkowania i uregulowania problemów osadniczych i rejestracyjnych miały miejsce w Królestwie Polskim - m.in. w Augustowie - w latach 1817-182024.

${ }^{20} \mathrm{~J}$. Wiśniewski, Dzieje osadnictwa w powiecie sejneńskim od XV do XIX wieku, w: Materiały do dziejów ziemi sejneńskiej, red. J. Antoniewicz, Białystok 1963, s. 153; E. Iwaniec, Z dziejów staroobrzędowców..., s. 79; Z. Jaroszewicz-Pieresławcew, Starowiercy w Polsce..., s. 19.

${ }^{21}$ E. Iwaniec, Z dziejów staroobrzędowców..., s. 80-81; Z. Jaroszewicz-Pieresławcew, Starowiercy w Polsce..., s. 19.

${ }^{22}$ E. Iwaniec, $Z$ dziejów staroobrzędowców..., s. 80, 83, 151; Z. Jaroszewicz-Pieresławcew, Starowiercy w Polsce..., s. 19.

23 J. Wiśniewski, Dzieje osadnictwa $w$ powiecie augustowskim od XV do XVIII wieku, w: Studia $i$ materiały do dziejów Pojezierza Augustowskiego, Białystok 1967, s. 13-294; E. Iwaniec, Z dziejów staroobrzędowców..., s. 99; Z. Jaroszewicz-Pieresławcew, Starowiercy w Polsce..., s. 19.

24 O. Hedemann, Historia powiatu brasławskiego, Wilno 1930, s. 281; E. Iwaniec, Z dziejów staroobrzędowców..., s. 69, 86; Z. Jaroszewicz-Pieresławcew, Starowiercy w Polsce..., s. 20-21. 
Pewna część starowierskich rodzin w wyniku zmiany granic państwowych stała się poddanymi pruskimi w latach $1795-1807^{25}$.

Podstawy prawne do osiedlania się starowierów w okolicach Mrągowa dało rozporządzenie króla Fryderyka Wilhelma III z 5 grudnia 1825 r. zwalniające starowierów ze służby wojskowej w pierwszym pokoleniu osadników, jeśli wykupili nieuprawną ziemię, na której się osiedlali. Król Fryderyk, wydając rozporządzenie, miał nadzieję, że osiedlanie się starowierów wpłynie korzystnie na zagospodarowanie niektórych terenów Prus. Początkowo zaproponowano starowierom niewielkiej wartości grunty w Puszczy Piskiej i w rewirach Krutyni i Mikołajek. W wyniku negocjacji z władzami pruskimi przyznano starowierom domenę Śmietki w powiecie mrągowskim, folwarki Skomacko i Ogródki oraz gospodarstwo we wsi Ogródek w powiecie ełckim. Przyznano im także folwarki w oleckim i powiecie piskim. Jednak ostatecznie starowierzy zrezygnowali z tego nadziału i postanowili, za zgodą władz, osiedlić się w nadleśnictwie Mikołajki i Krutyńn ${ }^{26}$.

Pierwszym osadnikiem w $1830 \mathrm{r}$. był Onufry Jakowlew (Smirnow), urodzony we wsi Dollman w guberni witebskiej. Osiedlił się on na wschód od Jeziora Bełdańskiego i na północny zachód od Wejsun. Wcześniej mieszkał w Sejnach, a później we wsi Pogorzelec. Wraz z kilkoma innymi osadnikami założył on wieś Onufryjewo i został wybrany jej pierwszym sołtysem ${ }^{27}$.

Kolejną wieś starowiercy nazwali Wojnowo na pamiątkę miejsca urodzenia (Wojnowo w guberni witebskiej) pierwszego przybysza Sidora Borysowa (Słowikowa). Oprócz tej nazwy funkcjonowała jeszcze oficjalna nazwa pruska Eckertsdorf od nazwiska nadleśniczego Eckerta, który pośredniczył po $1825 \mathrm{r}$. $\mathrm{w}$ rozmowach starowierów z władzami pruskimi. Sidor Borysow przed przyjazdem do Wojnowa mieszkał w Posejance w Suwalskiem. W tym samym czasie w Wojnowie osiedliło się łącznie 17 gospodarzy starowierskich ${ }^{28}$.

Kolejno powstało jeszcze siedem wsi, w których osiedlili się starowierzy. Były to: Gałkowo, Mościszki (zwane też Nikołajewem), Zameczek, Iwanowo (założona w 1840 r.), Ładne Pole (obecnie Śwignajno), Kadzidłowo, Piotrowo. W sumie osadnicy starowierscy założyli w powiecie mrągowskim 11 wsi. Mieszkali oni w rozproszeniu w innych powiatach. Według stanu na $1837 \mathrm{r}$. zamieszkiwali w powiatach piskim, węgorzewskim, gołdapskim, giżyckim, ełckim i oleckim ${ }^{29}$.

Różnego rodzaju problemy natury gospodarczej i pieniężnej, m.in. zatrudnianie przez starowierów jako parobków ludzi bez dokumentów, zmusiło władze pruskie do nałożenia na starowierów pewnych ograniczeń. Kwestią szczególną było wyrabianie paszportów. Starowierzy nie chcieli nosić nazwisk, twierdząc, że wystarcza im imię i otczestwo, i władzom z wielkim trudem udało się namó-

\footnotetext{
25 Z. Jaroszewicz-Pieresławcew, Starowiercy w Polsce..., s. 31.

26 Ibidem, s. 32.

27 Ibidem, s. 33.

28 Ibidem, s. 33-34.

29 Ibidem, s. 34.
} 
wić ich do przybierania nazwisk. Nazwiska te pochodziły od przezwisk lub były patronimikami, niekiedy pochodziły też od wykonywanych zawodów. Kiedy po pewnym czasie zaakceptowano nazwiska, okazało się, że nie wszyscy starowierzy pamiętają swoje przybrane nazwiska. Trzeba było zabrać się za porządkowanie nie tylko tego problemu, ale też innych trudności, związanych ze służbą wojskową, sprawami pełnoletności czy opieki nad małoletnimi ${ }^{30}$.

Ważną sprawą był problem oświaty i szkolnictwa. Już w 1847 r. wprowadzono obowiązek szkolny także dla dziewcząt. W Wojnowie szkoła powstała w $1876 \mathrm{r}$., w 1877 r. szkoła w Ładnym Polu, w 1882 r. szkoła w Mościskach, a w 1898 r. szkoła w Osiniaku. Były to szkoły dwuklasowe. Dzieci starowierów kończyły też trzyklasową szkołę w Ukcie. W 1878 r. wprowadzono nakaz uczęszczania do szkół państwowych. Wcześniej starowierzy utrzymywali nauczycieli domowych, najczęściej $\mathrm{z}$ własnego środowiska. Tacy nauczyciele pracowali w Wojnowie, Ładnym Polu, Piaskach. W pierwszych latach w szkołach posługiwano się językiem polskim, bo dzieci nie znały niemieckiego. Władze pruskie również z dorosłymi starowierami porozumiewały się początkowo $\mathrm{w}$ języku polskim ${ }^{31}$.

Warto zwrócić uwagę na organizację życia religijnego starowierów pierwszym okresie ich życia na Mazurach. Początkowo modlili się we własnych domach, a pierwsza świątynia powstała we wsi Ładne Pole. Ostatnie nabożeństwo odbyło się w niej w 1915 r. Później odprawiano tam tylko modlitwy za zmarłych. Świątynię tę rozebrano $\mathrm{w} 1935 \mathrm{r}$.

W 1840 r. wybudowano pierwszą molennę w Wojnowie. Spłonęła ona w 1921 r. i wówczas wzniesiono drugą, z zewnątrz przypominającą świątynię ewangelicką. Wkrótce w Wojnowie stanęła też molenna klasztorna. We wsi Wojnowo pierwsi mnisi mieszkali już około 1833 r., jednak wówczas nie było tam klasztoru, Pierwsza „pustelnia” powstała nad jeziorem Duś w 1836 r. i nazywana była grigoriczewyj skitok, bowiem jej założycielem był Łarentij Grigorjew Rastropin. Kolejne dwie pustelnie funkcjonowały na linii Starej Ukty (późniejsze Śwignajno) i we wsi Piaski. Eugeniusz Iwaniec twierdził, że staroobrzędowe skity na terenie Mazur funkcjonowały jeszcze przed założeniem wsi Wojnowo. Wyróżnia on też tak zwane bohomoły (jedna mniszka i dwóch mnichów) ${ }^{32}$.

W sumie dotarły do naszych czasów informacje o siedmiu klasztorach. Trzy z nich - jak pisała Zoja Jaroszewicz-Pieresławcew - są zaznaczone na mapie powiatu piskiego z 1877 r. Chodzi tu o klasztory onufryjewski i wojnowski (męskie) oraz majdański (żeński). W odległości 10-12 wiorst od wsi Kulinowo i wiorstę na północ od wsi Onufryjewo był klasztor, o którym nie zachowały się praktycznie żadne informacje, oprócz tego, że spłonął. Kolejny klasztor męski powstał nie-

30 Ibidem, s. 35-36.

${ }^{31}$ Ibidem, s. 36-38.

32 E. Iwaniec, Z dziejów staroobrzędowców..., s. 120-121; Z. Jaroszewicz-Pieresławcew, Starowiercy w Polsce..., s. 43. 
opodal Wojnowa w miejscu gdzie wcześniej funkcjonował grigoriczewyj skitok. To o tym klasztorze obszernie w wielu publikacjach pisał Eugeniusz Iwaniec, bowiem przełożonym tego klasztoru był Paweł Pruski (Piotr Iwanowicz Ledniew), który doprowadził klasztor do rozkwitu i był inicjatorem założenia tzw. Drukarni Słowiańskiej w Piszu. Do upadku klasztoru doprowadził rozłam wśród mnichów. Spowodowały go zmiana poglądów Pawła Pruskiego i jego 15 uczniów. Przeszli oni na jedinowierstwo. W 1884 r. majątek klasztorny stał się własnością jednego z wierzycieli, starowiera Uljana Sławikowa. Majątek ten odkupiła przeorysza spalonego klasztoru na Majdanie k. Wojnowa i przy wsparciu wspólnoty starowierów z Moskwy zorganizowała w tym miejscu nowy, żeński klasztor. Kolejny klasztor działał w odległości $15 \mathrm{~km}$ od Wojnowa, w miejscowości Pupy (Spychowo). W latach 70. XIX w., $2 \mathrm{~km}$ za wsią Onufryjewo postawił dwa budynki klasztorne i molennę Tichon Krymow. W klasztorze tym mieszkała jego córka Agata ${ }^{33}$.

Żeński klasztor w Wojnowie bardzo szybko się rozwinął. Stało się tak dlatego, że zamieszkały w nim nie tylko mniszki z innych mazurskich klasztorów starowierskich, ale też mniszki przybyłe z Moskwy. Przywoziły one ze sobą spory kapitał, który stawał się własnością klasztoru. Szczególny rozkwit monasteru przypadł na 1914 r. Mieszkały w nim wówczas 24 osoby. Oprócz mniszek byli to starcy, sieroty i jeden duchowny. W klasztorze istniały bardzo ściśle przestrzegane reguły, ponadto każda mniszka musiała pracować w klasztornym 100-morgowym gospodarstwie. W chwili wybuchu I wojny światowej w klasztorze mieszkało 65 osób. Po rozpoczęciu działań wojennych większość z nich została wywieziona do Zinten pod Królewcem. Rozgrabiono wówczas znaczną część majątku klasztornego. W 1925 r. w klasztorze było 12 mniszek i tyle samo nowicjuszek. W zimie, na przełomie 1928 i 1929 r., zmarzło większość drzewek z klasztornego sadu owocowego. W 1928 r. przełożona Jewpraksija (Jelena) Dikopolska przepisała majątek klasztorny na własność Antoniny Kondratjewej i częściowo Lidii Polentz. Kontakty mniszek z miejscową ludnością uległy zdecydowanemu ograniczeniu. Mniszki uczyły miejscowych starowierów jedynie zasad wiary, czyniły także próby werbunku kobiet do klasztoru. W 1930 r. gmina Wojnowo zorganizowała jubileusz stulecia osadnictwa starowierskiego na jej terenie. Mniszki nie wzięły udziału w uroczystościach, które odbyły się 13 lipca 1930 r. i były szeroko opisywane w prasie niemieckiej. Oprócz nabożeństwa odbył się festyn, korowód starowierów w strojach ludowych przemaszerował przez wieś, śpiewano rosyjskie pieśni ludowe, zorganizowano zawody sportowe. Położono także kamień upamiętniający stulecie osadnictwa starowierów ${ }^{34}$.

W okresie międzywojennym doszło też do zbliżenia starowierów z Mazur ze starowierami zamieszkałymi w Polsce. Inicjatorami zbliżenia byli starowierzy

${ }^{33}$ E. Iwaniec, Z dziejów staroobrzędowców..., s. 121-137; Z. Jaroszewicz-Pieresławcew, Starowiercy w Polsce..., s. 43-46.

${ }^{34}$ Z. Jaroszewicz-Pieresławcew, Starowiercy w Polsce..., s. 46-48. Należy dodać, że Iwaniec określa datę uroczystości na 20 lipca 1930 r.; E. Iwaniec, Z dziejów staroobrzędowców..., s. 142. 
z Wilna i Rygi. Delegacja starowierów z Mazur uczestniczyła - jako goście honorowi - w II Ogólnopolskim Zjeździe Staroobrzędowców, który odbył się w Wilnie w 1930 r. $^{35}$

Zasadniczą część recenzowanej pozycji stanowią wspomnienia Grigorija Jakowlewicza Krassowskiego (1895-1975), starowiera z Gałkowa na mazurach. Wspomnienia zostały poprzedzone krótkim wstępem autorstwa Stefana Pastuszewskiego. On też jest autorem szkicu zatytułowanego Świadectwo wyzwolonego staroobrzędowca, który stanowi drugą część książki i odgrywa rolę posłowia. Poznajemy w nim życiorys Grigorija Krasowskiego przedstawiony na tle życia mazurskich staroobrzędowców oraz obszerny opis przyczyn, dla których Pastuszewski zdecydował się wydać wspomnienia Krassowskiego.

Grigorij Jakowlewicz Krassowski urodził się 27 stycznia 1895 r. w miejscowości Schlosschen (obecnie Zameczek) w gminie Ukta. Zmarł 2 maja 1975 r. w Mrągowie. Był jednym z organizatorów wspomnianych obchodów jubileuszu 100-lecia staroobrzędowców na Mazurach. Jak twierdzi Pastuszewski (powtarzając za Iwańcem), z powodu czasowego pobytu Krassowskiego na Ukrainie obchody te zawierały ukraińskie zapożyczenia ${ }^{36}$.

Grigorij Krassowski w czasie II wojny światowej został wcielony do Wehrmachtu i skierowany na front inflancki, gdzie, jak sam twierdził, służył w sztabie. 14 listopada 1944 r. dostał się do niewoli radzieckiej, w której przebywał do października 1945 r. Władze radzieckie uważały starowierów za Niemców, dlatego Krassowski wraz z innymi jeńcami został wywieziony do radzieckiej strefy okupacyjnej Niemiec. Odnowił tam swoją wcześniejszą przynależność do Komunistycznej Partii Niemiec, pracował jako nauczyciel języka rosyjskiego. 19 maja 1947 r. powrócił do Polski i zamieszkał w Gałkowie. 29 maja 1947 r. złożył wniosek o stwierdzenie polskiej przynależności państwowej, w którym pisał, że jest Mazurem, urodził się na ziemi mazurskiej, mówi po polsku i pragnie zostać obywatelem Polski. Powiatowy Urząd Bezpieczeństwa Publicznego w Mrągowie nie miał zastrzeżeń co do przyznania polskiego obywatelstwa Krassowskiemu. W 1947 r. Krassowski wstąpił do Polskiej Partii Robotniczej. W latach 1947-1949 był sołtysem w Gałkowie i prezesem gminnej Samopomocy Chłopskiej. Przez pewien czas był też przewodniczącym rady parafialnej w Wojnowie, chociaż był praktycznie indyferentny religijnie (do tego wątku jeszcze powrócę). W ramach czystek partyjnych 31 października $1948 \mathrm{r}$. został wydalony z PPR, za „wysoką funkcję w Wehrmachcie”. 30 lipca 1965 r. Egzekutywa PZPR w Olsztynie przywróciła mu członkostwo w partii z zaliczeniem ciągłości stażu od momentu wydalenia.

35 Z. Jaroszewicz-Pieresławcew, Starowiercy w Polsce..., s. 48.

36 S. Pastuszewski, Świadectwo wyzwolonego staroobrzędowca, w: idem, Wspomnienia mazurskiego filipona..., Bydgoszcz 2014, s. 41. 
Opis życia Grigorija Krassowskiego pióra Stefana Pastuszewskiego jest niepełny. Poza przytoczonymi wyżej informacjami dowiadujemy się jeszcze, że w roku 1914 został zmobilizowany i skierowany do 82. pułku artylerii lekkiej w Ostródzie. Walczył w Kurlandii, Południowej Galicji, Bukowinie, Francji. Wiosną 1918 r. został ranny i trafił do szpitala, a potem do sanatorium. W listopadzie $1918 \mathrm{r}$. wrócił do Gałkowa i leczył się w szpitalu w Mrągowie. W latach 1920-1930 Krassowski przebywał na Ukrainie, a ściślej - na Podolu, gdzie pracował jako ekonom. W roku 1930 powrócił na Mazury i w Gałkowie, Wojnowie i Krutyni założył komórkę KPD. Pastuszewski twierdzi, że 18 czerwca 1944 r. Grigorij Krassowski wziął ślub cywilny z wdową Anną Szczerbakowską z domu Słowikow, która zmarła w 1945 r. W 1956 r. Krassowski został współpracownikiem Komitetu ds. Bezpieczeństwa Publicznego, przyjmując pseudonim „Wossark”. Jednak bardzo szybko zerwano z nim współpracę, odnotowując, że się "nie nadaje”. Prawdopodobnie powodem była zbytnia gadatliwość i skłonność do konfabulacji, o której często wspomina autor szkicu. Krassowski był też dostarczycielem wielu cennych informacji źródłowych dla Iwańca podczas jego pracy nad monografią $Z \dot{z} y c i a$ staroobrzędowców na ziemiach polskich $w X V I I-X X w$. Korespondencyjnie odpowiadał na wiele pytań, zapewne wcześniej sam szukając odpowiedzi. Wraz z proboszczem parafii prawosławnej w Wojnowie w latach 1971-1982 ks. Aleksandrem Makalem dokonał zestawienia nazwisk staroobrzędowców (bezpopowców i jedinowierców) na Mazurach w 1968 r. Często pomagał swym współwyznawcom pisać różne pisma do urzędów PRL, w tym wnioski o emerytury i renty niemieckie. Według Pastuszewskiego, Krassowski miał fantazyjną osobowość oraz „prowadził się niemoralnie”, co było powodem odsunięcia się od niego wielu ludzi. Jednak - jak zauważa autor - wszystko zostało mu przebaczone, bowiem zmarł w Wielki Piątek (podobnie jak Jezus Chrystus), co dla pobożnych starowierów miało duże znaczenie religijne i... moralne ${ }^{37}$.

Szkic Stefana Pastuszewskiego dostarcza wielu cennych informacji o życiu codziennym i miejscu trwania starowierów na Mazurach, jednak - czego nie można nie zauważyć - sprawia wrażenie chaotycznego. Jest podzielony na kilka części, które nie stanowią ciągu chronologicznego, a informacje w nich zawarte często charakteryzują się również przemieszaniem wątków. W krótkiej części pierwszej autor podaje czas, w jakim zostały spisane wspomnienia Grigorija Krassowskiego, wspomina o jego współpracy z Eugeniuszem Iwańcem, ks. Aleksandrem Makalem oraz informuje o społecznym zaangażowaniu w życie wspólnoty staroobrzędowej i współpracy z organami bezpieczeństwa PRL. Druga część zawiera najwięcej faktów z życia Krassowskiego (do 1949 r.) i chyba jest najbardziej spójna. W krótkiej części trzeciej z kolei autor podaje informacje bibliograficzne o rękopisie wspomnień Krassowsiego i opisuje własną metodologię wydawniczą tych wspomnień. W części czwartej kreśli zakres chronologiczny wspomnień Krassowskiego i zwraca uwagę na ich cechy dotyczące charakteru życia staroobrzędowców na Mazurach i poza nimi,

37 Ibidem, s. 40-42, 46-47, 49, 57. 
ich związkach z Niemcami, kontaktach z Polakami i sytuacji politycznej ówczesnych Mazur. W to wplecione zostały nieliczne wątki z biografii Krassowskiego. W kolejnej porusza wątki dotyczące procesów asymilacyjnych i dezintegracyjnych wśród mazurskich staroobrzędowców. Mówi o ich tożsamości oraz o stosunku do nich państwa niemieckiego. W części szóstej zwraca uwagę na brak wątków wyznaniowych we wspomnieniach Krassowskiego, co tłumaczy nie tylko zlaicyzowanym światopoglądem autora, ale również wpływem niemieckiej XIX-wiecznej sekularyzacji. Kolejna część jest poświęcona światopoglądowi Krassowskiego, jego tożsamości etniczno-kulturowej oraz wyjaśnieniu, dlaczego nazywał siebie filiponem, a nie staroobrzędowcem w sensie konfesyjnym. Następny fragment zawiera szerokie wyjaśnienie pojęcia „filiponi” z uzasadnieniem historycznym. Później w kolejnej części - autor powrócił do opisu światopoglądu Krassowskiego i jego lewicowych poglądów, co w nawiązaniu do fragmentu wspomnień dotyczących działalności niemieckiego KPD prowadzi go do wniosku, że fragment ten był stylizacją na potrzeby czytelnika związanego z PRL-owską władzą (swoje wspomnienia Krassowski spisywał bowiem na przełomie lat 60. i 70. XX w.). W części kolejnej Pastuszewski kładzie nacisk na styl pisarski Krassowskiego, który wiąże ze skłonnościami do konfabulacji i wyolbrzymiania pewnych wątków. Zwraca też uwagę na język wspomnień, niekiedy zbliżony do gwary mazurskiej, ale też pełen rusycyzmów i germanizmów, co m.in. doprowadziło go do wniosku, że Krassowski był trójjęzyczny, podobnie jak znaczna część mazurskich starowierów, chociaż zależnie od okresu i historycznych zawirowań zmieniały się preferencje i dominacje językowe. Oczywiste jest, co podkreśla również Pastuszewski, że w pokoleniu Krassowskiego pierwszym językiem był rosyjski z naleciałościami gwarowymi, a drugim - poprzez szkołę - niemiecki. Pastuszewski opisuje również nierówność stylu i potknięcia gramatyczne autora wspomnień, chociaż uważa, że miał on dużą sprawność językową.

Konstrukcja szkicu Pastuszewskiego, jak wspomniałem, budzi zastrzeżenia. Lepszym zabiegiem, w ocenie recenzenta, byłoby opisanie w pierwszej części pracy życiorysu Krassowskiego i odniesienie się do relacji pomiędzy filiponami a staroobrzędowcami, a także poruszenie kwestii tożsamościowych wśród staroobrzędowców mazurskich. Środkową część szkicu stanowiłyby kwestie historyczne odnoszące się do okresu wspomnień Krassowskiego, a część ostatnią - wszelkie uwagi dotyczące tekstu wspomnień. Taki podział byłby uzasadniony zarówno chronologicznie, jak i metodologicznie.

Interesujący w szkicu Stefana Pastuszewskiego jest fragment odnoszący się do określenia „filiponi”, jego pochodzenia i używania wobec starowierów. Jak słusznie zauważył autor szkicu, nazwy „filiponi” używano początkowo w odniesieniu do wszystkich starowierów, bez względu na przynależność do jakiegokolwiek ich odłamu (tołku, sogłasija). Termin „filiponi” funkcjonował na obszarze Rzeczypospolitej od XVIII do początku XIX w., gdy został zastąpiony przez termin „starowierzy”, co propagowali wyznawcy. Nazwa „filiponi” pojawiała się jednak 
jeszcze na początku XX w., o czym świadczy chociażby wspominana tu już praca ks. Karola Dębińskiego, kanonika katedry lubelskiej, Raskoł i sekty prawosławnej Cerkwi Rosyjskiej, w której o przesiedleniu się części starowierów do Polski, autor pisał: „Ponieważ Filipowcy występowali otwarcie przeciw panującemu, nie chcąc się zań modlić, rząd zaczął ich surowo prześladować i z tego powodu, znaczna ich część przesiedliła się do Polski, Prus i na Wołoszczyznę" ${ }^{38}$. Według Pastuszewskiego termin ten przetrwał do dzisiaj i jest używany na określenie starowierów, m.in. na Wołyniu, Podolu, Bukowinie, Mołdawii czy Budziaku.

Autor omawia też genezę nazwy „filiponi”, w moim przekonaniu słusznie polemizując $\mathrm{z}$ legendarnymi opowieściami o mnichu Filipie, który miał być założycielem tego odłamu i ihumenem klasztoru wygowskiego nad Morzem Białym $^{39}$. Pastuszewski jest zdania, że termin „filiponi” został rozpowszechniony przez unickiego mnicha i badacza Ignacego Kulczyckiego w pracy Specimen ecclesiae Rutheniae, wydanej w Rzymie w 1733 r. Podstawą źródłową był natomiast protokół sporządzony w 1690 r. przez Piotra Połtiewa, komisarza i inkwizytora sądu zadwornego na podstawie odpowiedzi udzielanych przez starowierów z Wietki na zadawane pytania. Oznacza to, że nazwa filiponi, niezależnie od jej pochodzenia, była używana przez samych staroobrzędowców na określenie własnej grupy wyznaniowej już pod koniec XVII w.

Jak już mówiłem, wspomnienia Grigorija Krassowskiego zostały wydane z niezwykłą starannością, która przejawiła się w możliwie najmniejszej ingerencji w oryginalny tekst. W wydanym tekście zachowano nie tylko oryginalną pisownię i styl autora wspomnień, ale również zaznaczono miejsca oryginalnych stron zeszytu, w którym wspomnienia te zostały spisane. Dodano jedynie przypisy tłumaczące niektóre sformułowania użyte przez autora lub wyjaśniające w bardzo zwięzłej formie, kim były postaci wspominane przez pamiętnikarza.

Jak każde wspomnienia, również te spisane przez Krassowskiego są materiałem subiektywnym, przefiltrowanym przez pamięć i poglądy ich autora. Często dotyczą jakichś lokalnych, fragmentarycznych spraw, których weryfikacja jest praktycznie niemożliwa. Niemniej we wspomnieniach Krassowskiego daje się dostrzec na przykład zły obraz stosunków prusko-polskich przed wybuchem I wojny światowej, a zarazem stosunkowo dobre relacje pomiędzy filiponami a przedstawicielami władz pruskich lub pruskich elit. Te dobre relacje uległy znacznemu pogorszeniu w przededniu wybuchu wojny. Konsekwencją takiego kształtu stosunków narodowościowych (oprócz, oczywiście, przynależności państwowej) była walka ramię w ramię z Niemcami podczas I wojny światowej, a później podczas plebiscytu 1920 r. opowiedzenie się praktycznie w 100\% za Niemcami. Tutaj warto zauważyć,

${ }^{38}$ K. Dębiński, Raskoł i sekty Prawosławnej Cerkwi Rosyjskiej. Szkic historyczny, Warszawa 1910, s. 55.

39 Legenda ta wciąż jest żywa, o czym świadczą opisy początków starowierów w Rosji zamieszczone na stronie internetowej: http://www.philipponia.republika.pl/, powołujące się na badania Emilii Sukertowej-Biedrawiny. 
że starowierzy, a przynajmniej jakaś ich część, niechętnie szli do wojska, co można tłumaczyć względami religijnymi. Ważne miejsce we wspomnieniach zajmuje również okres walki Krassowskiego na froncie I wojny światowej i odniesiona tam kontuzja. Autor też praktycznie zawsze dobrze wyraża się o Polakach, wspomina pomoc udzielaną przez niektórych miejscowych (Mazurów) starowierskiemu klasztorowi. Również siebie nazywa przyjacielem Polaków. Wspomina, że już po plebiscycie chciał wyjechać do Polski, ale władze nie wyraziły na to zgody.

Niewiele miejsca we wspomnieniach Krassowskiego zajmują sprawy wyznaniowe. Autor mówi o internowaniu w Korszach mniszek wraz z przełożoną Jewpraksią (Jeleną) Dikopolską oraz o rewizji dokonanej przez Niemców po tym fakcie. Przy tej okazji wspomina o niemieckim żołnierzu, który strzelił do ikony Zbawiciela i ją przedziurawił; za ten czyn miała go ponoć spotkać kara, bowiem poniósł śmierć w pierwszej wojennej potyczce. Podczas rewizji klasztor został też okradziony z wielu ikon, a pozostałe uszkodzono. Krassowski opisuje okoliczności śmierci w 1919 r. dwóch starowierów zabitych przez żandarmów oraz pogrzeb jednego z nich, Timofieja Makarowskiego. Żegnali go w Wojnowie licznie przybyli zarówno starowierzy jak i ewangelicy. Jak pisał Krassowski: „Przyszedł dzień pogrzebowy Timofieja, piękny, pełny słońca, do tego narodu, bez różnicy starości, wiary i narodowości [...] Na cmentarzu nie było dla wszystkich miejsca [...] I dzisiaj wspominam i mówię, że nikt nie miał takiego, wspaniałego pogrzebu w naszej parafiji” ${ }^{\prime \prime}$. Fragmenty te mogą świadczyć o tym, że Krassowski mimo deklarowanej obojętności religijnej, czuł związek ze swoją religijną wspólnotą i nieobce mu były pewne przejawy egzaltacji religijnej i mistycyzmu.

Wspomnienia Grigorija Krasowskiego stanowią unikalny dokument dotyczący dziejów mazurskich starowierów. Dlatego, mimo miejscami chaotycznego stylu pisarskiego i mnogości zwrotów rosyjskich lub niemieckich, stanowią one cenny materiał historyczny, obrazujący postawy starowierów wobec burzliwych przemian społecznych i politycznych w pierwszych dekadach XX w. Dołączony szkic pióra Stefana Pastuszewskiego jest natomiast doskonałym uzupełnieniem tych wspomnień, nie tylko przynoszącym wiedzę o samych starowierach, ale też ukazującym szerokie tło wydarzeń. Dzięki temu czytelnikowi łatwiej jest zrozumieć spolaryzowanie postaw, szczególnie młodszego pokolenia, starowierów w okresie I wojny światowej i ich zbliżenie do otoczenia, co w konsekwencji przyniosło fale migracji lub obojętnienia religijnego, od czego nie był wolny sam autor wspomnień i jego rodzina. Postawy te żywe były jeszcze wśród mazurskich filiponów, w latach 80 . XX w., o czym piszący te słowa mógł sam się przekonać, przebywając kilkakrotnie w Wojnowie i okolicach, a co - jak słusznie zauważa Pastuszewski - spowodowało, że „dziś obecność filiponów w tym regionie jest więcej niż symboliczna”"41.

${ }^{40}$ G. Krassowski, Wspomnienia mazurskiego filipona, oprac., wydał i posłowiem opatrzył S. Pastuszewski, Instytut Wydawniczy Świadectwo, Bydgoszcz 2014, s. 29.

${ }^{41}$ S. Pastuszewski, Wstęp, w: G. Krassowski, op. cit., s. 5. 